\title{
Pengaruh Potongan Harga, Iklan, dan Kualitas Produk terhadap Keputusan Pembelian di Shopee
}

\author{
* Refita Alce \\ Program Studi Manajemen Fakultas Ekonomi dan Bisnis \\ Universitas Bhayangkara Surabaya, Indonesia
}

DOI: $10.46821 /$ benchmark.v2i1.224

\begin{abstract}
Abstrak
Tujuan dari penelitian ini adalah untuk mengetahui pengaruh potongan harga, iklan dan kualitas produk baik secara parsial maupun simultan terhadap keputusan pembelian di Shopee. Jenis penelitian ini adalah kuantitatif dengan metode survei. Sampel dalam penelitian ini sebanyak 100 responden dengan menggunakan metode Simple random sampling, yakni pengambilan anggota sample dari populasi dilakukan secara acak tanpa memperhatikan strata yang ada dalam populasi tersebut. Teknik analisis data menggunakan analisis regresi linier berganda disertai uji $\mathrm{F}$ (simultan) dan uji t (parsial). Proses perhitungan menggunakan SPSS 25.0. Hasil pengujian menunjukkan bahwa potongan harga dan iklan secara parsial berpengaruh signifikan terhadap keputusan pembelian di Shopee, sedangkan kualitas produk secara parsial tidak berpengaruh signifikan terhadap keputusan pembelian di Shopee. Faktor yang sangat berpengaruh terhadap kep utusan pembelian di Shopee adalah kualitas produk.
\end{abstract}

Kata Kunci: Potongan Harga, Iklan, Kualitas Produk, Keputusan Pembelian.

\begin{abstract}
The purpose of this study was to determine the effect of price discounts, advertising, and product quality either partially or simultaneously on purchasing decisions at Shopee. This type of research is quantitative with a survey method. The sample in this study was 100 respondents using the simple random sampling method, which is based on the criteria of Shopee users at Bhayangkara University Surabaya who have made purchases at Shopee more than once. The data analysis technique used multiple linear regression analysis with $\mathrm{F}$ test (simultaneous) and $\mathrm{t}$ test (partial ). The calculation process uses SPSS 25.0. The test results show that price and advertising partially have a significant effect on purchasing decisions at Shopee, while product quality partially has no significant effect on purchasing decisions at Shopee. The most influential factor in purchasing decisions at Shopee is product quality.
\end{abstract}

Keywords: Discounts, Advertising, Product Quality, Purchase Decision.

\section{PENDAHULUAN}

Pada era globalisasi saat ini perkembangan teknologi dan informasi di dunia khususnya internet mengalami perkembangan yang sangat pesat. Salah satu hasil dari kemajuan teknologi informasi setelah era surat kabar, radio, televisi adalah teknologi komputer yang saat ini memegang peran penting dalam penyebaran informasi dan akan terus berkembang di tambah dengan adanya internet. Internet dapat menghubungkan satu orang dengan orang lainnya, serta menyediakan informasi sebagai sarana hiburan, maupun sebagai sarana komunikasi. Menurut Kim dan Mood

*Corresponding Author:

Hal: 81-93

Email: refitaalce98@gmail.com 
dalam Pratama (2015:2), internet adalah proses untuk mengantar kan informasi, produk, layanan, dan proses pembayar an melalui kabel telepon, koneksi internet dan akses digital lainnya. Internet dapat memberikan informasi untuk masyarakat tanpa dibatasi oleh lokasi dan waktu. Hal ini membuat masyarakat menyadari bahwa teknologi komunikasi denga n menggunakan internet menjadi kebutuhan pokok bagi sebagian besar orang selain kebutuhan pangan, sandang, dan papan.

Selain menghadapi era globalisasi, perusahaan-perusahaan di Indonesia juga menghadapi tantangan yang terkait dengan MEA. Masyarakat Ekonomi ASEAN atau yang biasa disingkat menjadi MEA secara singkatnya bias diartikan sebagai bentuk integrase Ekonomi ASEAN yang artinya semua Negara-negara yang berada dikawasan Asia Tenggara (ASEAN) menerapkan system perdagangan bebas (Nesadurai, 2015:39).

Menurut Tjiptono (2015:166), diskon merupakan potongan harga yang diberikan oleh penjual kepada pembeli sebagai penghargaan atas aktivitas tertentu dari pembeli yang menyenangkan bagi penjual.

Menurut pendapat Durianto dan Liana dalam Fitriah (2018:12), iklan adalah semua bentuk aktivitas untuk menghadirkan dan mempromosika $\mathrm{n}$ ide, barang, atau jasa secara nonpersonal yang dibayar oleh sponsor tertentu.

Menurut Kotler dan Keller (2016:164), kualitas produk adalah kemampua n suatu barang untuk memberikan hasil atau kinerja yang sesuai bahkan melebihi dari apa yang di inginkan pelanggan.

Menurut Abdurrahman (2015:41) Keputusan pembelian, yaitu keputusan konsumen untuk membeli atau tidak membeli suatu produk atau jasa merupakan alternatif yang penting bagi pemasar. Keputusan pembelian merupakan salah satu tahapan dalam proses keputusan pembelian sebelum perilaku pasca pembelian. Dalam memasuki tahap keputusan pembelian sebelumnya konsumen sudah dihadapkan pada beberapa pilihan alternatif sehingga pada tahap ini konsumen akan melakukan aksi untuk memutuskan untuk membeli produk berdasarkan pilihan yang ditentukan.

Berkembangnya teknologi, informasi, komunikasi dan pengetahuan diharapkan mampu menambah daya tarik konsumen untuk membeli produk mereka, sehingga mampu memberikan profit yang cukup menguntungkan bagi perusahaan. Shopee, diharapkan dapat meningkatkan daya keputusan pembelian konsumennya dan mampu bersaing dengan para e-commerce yang menjual produk yang sama.

\section{TINJAUAN PUSTAKA}

\section{Potongan Harga}

Kotler dan Amstrong (2016), mendefinisikan potongan harga sebagai pengurangan langsung terhadap harga dalam pembelian pada masa tertentu suatu waktu atau dalam kuantitas besar.

Sedangkan menurut Tjiptono dalam Jurnal Della Ruslimah Sari (2018:53), diskon merupakan potongan harga yang diberikan oleh penjual kepada pembeli sebagai harga atas aktivitas tertentu.

\section{Iklan}

Menurut pendapat Durianto dan Liana dalam Fitriah (2018:12), iklan adalah semua bentuk aktivitas untuk menghadirkan dan mempromosikan ide, barang, atau jasa secara nonpersonal yang dibayar oleh sponsor tertentu. 
Sedangkan menurut Kotler dan Keller (2016:631), iklan adalah pembayaran apapun dari presentasi nonpersonal dan promosi ide, atau layanan oleh sponsor yang teridentifikasi.

\section{Kualitas Produk}

Menurut Kotler (2016:143), kualitas produk merupakan alat untuk menyampaikan hasil atau kinerja yang sesuai, atau bahkan melebihi apa yang diinginkan pelanggan.

Sedangkan menurut Garvin dalam buku Fandy Tjiptono (2016:134), mendefinisikan kualitas produk merupakan suatu penilaian konsumen terhadap keunggulan atau keistimewaan apabila produk tersebut memenuhi harapan konsumen.

\section{Keputusan Pembelian}

Menurut Kotler dan Keller (2016:177), mendefinisikan keputusan pembelian sebagai berikut "Consumer behaviour is the study of how individual, groups, and organizations select, buy use, and dispose of goods, services, ideas, or experiences to satisfy their needs and wants" yang artinya keputusan pembelian merupakan bagian dari perilaku konsumen yaitu studi tentang bagaimana individu, kelompok, dan organisasi memilih, membeli, menggunakan, dan bagaimana barang, jasa, idea, atau pengalaman untuk memuaskan kebutuhan dan keingi nan

mereka.

\section{Hipotesis Penelitian}

Berdasarkan teori dan beberapa penelitian yang di uraikan diatas maka di dapat hipotesis sebagai berikut :

a. Bahwa variabel potongan harga, iklan, dan kualitas produk secara simultan berpengaruh signifikan terhadap keputusan pembelian di Shopee studi kasus Universitas Bhayangkara Surabaya.

b. Bahwa variabel potongan harga, iklan, dan kualitas produk secara parsial berpengaruh signifikan terhadap keputusan pembelian di Shopee studi kasus Universitas Bhayangkara Surabaya.

c. Bahwa variable kualitas produk yang berpengaruh dominan terhadap keputusan pembelian di Shopee studi kasus Universitas Bhayangkara Surabaya.

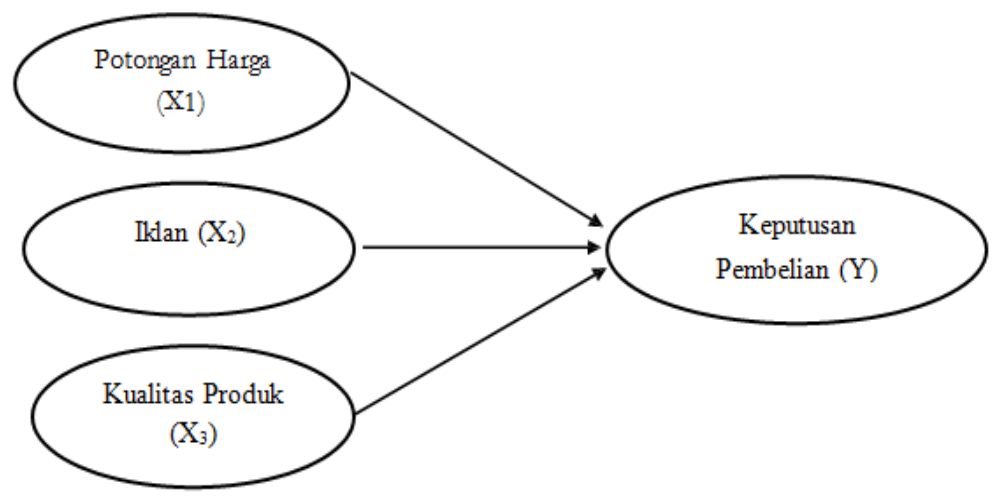

Gambar 1

Kerangka Konseptual 
METODE PENELITIAN

\section{Lokasi dan Waktu Penelitian}

Lokasi dari objek penelitian ini adalah Pengguna Shopee di Universias Bhayangkara Surabaya yang beralamatkan di Jalan Ahmad Yani No.14, Ketintang, Gayungan, Surabaya. Waktu penelitian ini dilaksanakan mulai bulan Februari 2021 sampai dengan data yang diperlukan lengkap untuk melaksanakan survey lapangan dan pengumpulan data yang dibutuhkan oleh peneliti.

\section{Sumber Data}

Sumber data yang digunakan dalam penelitian ini dengan mengumpulkan data melalui penyebaran kuesioner kepada subyek penelitian yang akan dituju yaitu mahasiswa pengguna shopee di Universitas Bhayangkara Surabaya. Selain itu data juga diperoleh dari buku besar dan literatur lain yang dapat menunj ang penulisan.

\section{Metode Pengumpulan Data}

Adapun teknik pengumpulan data yang sangat menunjang terselenggaranya penelitian dengan digunakan cara-cara pengumpulan data adalah:

a. Metode Kuesioner

Metode kuesioner merupakan teknik pengumpulan data yang dilakukan dengan cara memberi seperangkat pertanyaan atau pernyataan tertulis kepada responden untuk dijawabnya (Sugiyono, 2016:142). Dalam penelitian ini penulis menggunakan metode kuesioner dengan cara memberi seperangkat pernyataan tertulis kepada responden untuk dijawab.

b. Metode Wawancara

Metode wawancara digunakan sebagai teknik pengumpulan data apabila peneliti ingin melakukan studi pendahuluan untuk menemukan permasalahan yang harus diteliti, dan juga apabila peneliti ingin mengetahui hal -hal dari responden yang lebih mendalam dan jumlah respondennya sedikit/kecil (Sugiyono, 2016:173).

\section{Pengujian Data \\ Uji Validitas}

Uji validitas merupakan derajat ketepatan antara data yang terjadi pada obyek penelitian dengan daya yang dapat dilaporkan oleh peneliti. "Data yang valid adalah data "yang tidak berbeda" antara data yang dilapor kan oleh peneliti dengan data yang sesungguhnya terjadi pada obyek penelitian (Sugiyono, 2018:267).”

\section{Uji Reliabilitas}

Uji reliabilitas adalah suatu instrumen cukup dapat dipercaya untuk digunakan sebagai alat pengumpul data karena instrumen tersebut sudah baik Uji reliabilitas dapat dilakukan dengan menghitung Cronbach Alpha masing-masing item dengan bantuan SPSS for Windows. Suatu instrument dikatakan reliabel jika mempunyai nilai alpha positif dan lebih besar dari 0,6. Dimana semakin besar nilai alpha, maka alat pengukur yang digunakan semakin handal. (Sugiyono, 2016:183).” 
Analisis Regresi Linier Berganda

Menurut Rachman (2017:89), regresi linier berganda adalah model regresi berganda jika variabel terikatnya berskala data interval atau rasio (kuantitatif atau numerik).

\section{Uji Hipotesis Pertama (Uji F)}

Uji statistik F pada dasarnya menunjukkan apakah semua variabel bebas yang dimaksudkan dalam model mempunyai pengaruh secara bersama -sama terhadap variable terikat. Dalam penelitian ini pengujian hipotesis secara simultan dimaksudkan untuk mengukur besarnya pengaruh variabel bebas terhadap variabel terikat.

\section{Uji Hipotesis Kedua (Uji t)}

Uji t pada pengujian ini bertujuan untuk menguji pengaruh variabel bebas terhadap variabel terikat.

\section{Uji Hipotesis Ketiga (Variabel yang Dominan)}

Variabel yang memiliki koefisien $(\beta)$ beta terbesar merupakan variabel bebas $(X)$ yang dominan pengaruhnya terhadap variabel terikat (Y) (Ghozali, 2016:56).

\section{HASIL ANALISIS DAN PEMBAHASAN}

\section{Uji Validitas}

Tabel 1 menunjukkan bahwa dari indikator-indikator variabel yang digunakan dalam penelitian ini semuanya memiliki nilai kolerasi diatas 0,197. Hal ini berarti bahwa semua indikator yang digunakan untuk mengukur semua variabel dalam penelitian ini dinyatakan mempunyai validitas yang tinggi.

\section{Uji Reliabilitas}

Berdasarkan Tabel 2 dapat diperoleh hasil pengujian yang dilakukan terhadap reliabilitas kuesioner diperoleh hasil bahwa nilai Cronbach's Alpha kesemua variabel lebih besar dari 0,05. Kondisi ini memberikan arti bahwa seluruh variabel tersebut adalah reliabel dan dapat digunakan pada analisis selanjutnya.

\section{Analisis Regresi Linier Berganda}

Dari tabel 3, maka dapat disusun persamaan regresi linear berganda sebagai berikut:

$\mathrm{Y}=1.206+0,599 \mathrm{X} 1+-0,176 \mathrm{X} 2+0,758 \mathrm{X} 3$

Persamaan regresi linear berganda yang terdapat pada Tabel 3, maka dapat dianalisis sebagai berikut:

a. Konstanta $(\alpha)$ sebesar 1.206 memberi arti apabila variabel bebas Potongan Harga, Iklan, dan Kualitas Produk adalah bernilai konstan, maka besarnya variabel terikat Keputusan Pembelian bernilai sebesar 1.206 satuan.

b. Potongan Harga (X1) memiliki nilai koefisien sebesar 0,599. Hal ini menandakan bahwa koefisien variabel Potongan Harga (X1) memiliki pengaruh positif (searah) terhadap Keputusan Pembelian (Y) di Shopee. Apabila Potongan Harga bertambah satu satuan, maka Keputusan Pembelian akan bertambah sebesar 0,599 satuan. Artinya semakin tinggi nilai Potongan Harga maka semakin tinggi Keputusan Pembelian. 
c. Iklan (X2) memiliki nilai koefisien sebesar 0,176. Hal ini menandakan bahwa koefisien variabel Iklan (X2) memiliki pengaruh positif (searah) terhadap Keputusan Pembelian (Y) di Shopee. Apabila Iklan bertambah satu satuan, maka Keputusan Pembelian akan bertambah sebesar 0,176 satuan. Artinya semaki n tinggi nilai Iklan maka semakin tinggi Keputusan Pembelian.

d. Kualitas Produk (X3) memiliki nilai koefisien sebesar 0,758. Hal ini menandakan bahwa koefisien variabel Kualitas Produk (X3) memiliki pengaruh positif (searah) terhadap Keputusan Pembelian (Y) di Shopee. Apabila Kualitas Produk bertambah satu satuan, maka Keputusan Pembelian akan bertambah sebesar 0,758 satuan. Artinya semakin tinggi nilai Kualitas Produk maka semakin tinggi Keputusan Pembelian.

Jadi variabel bebas yang terdiri dari Potongan Harga, Iklan, dan Kualitas Produk memiliki pengaruh yang positif atau searah terhadap variabel terikat Keputusan Pembelian.

\section{Tabel 1}

Hasil Pengujian Validitas Instrumen Potongan Harga (X1), Iklan (X2), dan Kualitas Produk (X3) terhadap Keputusan Pembelian (Y) Studi Kasus Pengguna Shopee Di Universitas Bhayangkara Surabaya Tahun 2021

\begin{tabular}{|c|c|c|c|}
\hline Variabel/indikator & Nilai $\mathrm{r}$ & $\mathrm{r}$ table & Keterangan \\
\hline \multicolumn{4}{|c|}{ Potongan Harga (X1) } \\
\hline $\mathrm{X} 1.1$ & 887 & Nilai $r>0,197$ & Valid \\
\hline $\mathrm{X} 1.2$ & 914 & Nilai $r>0,197$ & Valid \\
\hline $\mathrm{X} 1.3$ & 768 & Nilai $r>0,197$ & Valid \\
\hline \multicolumn{4}{|c|}{ Iklan (X2) } \\
\hline $\mathrm{X} 2.1$ & 826 & Nilai $r>0,197$ & Valid \\
\hline $\mathrm{X} 2.2$ & 770 & Nilai $r>0,197$ & Valid \\
\hline $\mathrm{X} 2.3$ & 712 & Nilai $r>0,197$ & Valid \\
\hline $\mathrm{X} 2.4$ & 683 & Nilai $r>0,197$ & Valid \\
\hline $\mathrm{X} 2.5$ & 826 & Nilai $r>0,197$ & Valid \\
\hline \multicolumn{4}{|c|}{ Kualitas Produk (X3) } \\
\hline X3.1 & 657 & Nilai $r>0,197$ & Valid \\
\hline $\mathrm{X} 3.2$ & 917 & Nilai $r>0,197$ & Valid \\
\hline X3.3 & 822 & Nilai $r>0,197$ & Valid \\
\hline $\mathrm{X} 3.4$ & 917 & Nilai $r>0,197$ & Valid \\
\hline $\mathrm{X} 3.5$ & 762 & Nilai $r>0,197$ & Valid \\
\hline \multicolumn{4}{|c|}{ Keputusan Pembelian $(\mathrm{Y})$} \\
\hline Y1 & 909 & Nilai $r>0,197$ & Valid \\
\hline $\mathrm{Y} 2$ & 944 & Nilai $r>0,197$ & Valid \\
\hline $\mathrm{Y} 3$ & 627 & Nilai $r>0,197$ & Valid \\
\hline Y4 & 666 & Nilai $r>0,197$ & Valid \\
\hline Y5 & 863 & Nilai $r>0,197$ & Valid \\
\hline
\end{tabular}

Sumber: Data Diolah Peneliti (2021) 
Tabel 2

Hasil Pengujian Reliabilitas

\begin{tabular}{lccc}
\hline \multicolumn{1}{c}{ Variabel } & Cronbach's aplha & Nilai Kritis & Keterangan \\
\hline Potongan Harga (X1) & 0,849 & & Reliable \\
Iklan (X2) & 0,797 & \multirow{2}{*}{0,05} & Reliable \\
Kualitas Produk (X3) & 0,809 & & Reliable \\
Keputusan Pembelian (Y) & 0,807 & & Reliable \\
\hline
\end{tabular}

Sumber: Data Diolah Peneliti (2021)

Tabel 3

Coefficients $^{\mathrm{a}}$

\begin{tabular}{|c|c|c|c|c|c|c|}
\hline \multirow{2}{*}{\multicolumn{2}{|c|}{ Model }} & \multicolumn{2}{|c|}{ Unstandardized Coefficients } & \multirow{2}{*}{$\begin{array}{c}\text { Standardized } \\
\text { Coefficients }\end{array}$} & \multirow[b]{2}{*}{$\mathrm{t}$} & \multirow[b]{2}{*}{ Sig. } \\
\hline & & $\mathrm{B}$ & Std. Error & & & \\
\hline \multirow[t]{4}{*}{1} & (Constant) & 1.206 & .420 & & 2.875 & .005 \\
\hline & Potongan Harga & .599 & .069 & .379 & 8.736 & .000 \\
\hline & Iklan & -.176 & .064 & -.168 & -2.742 & .007 \\
\hline & Kualitas Produk & .758 & .074 & .785 & 10.202 & .000 \\
\hline
\end{tabular}

a. Dependent Variable: Keutusan Pembelian

Sumber: Data Diolah Peneliti (2021)

Tabel 4

ANOVA $^{\mathrm{a}}$

\begin{tabular}{|c|c|c|c|c|c|c|}
\hline Model & & Sum of Squares & Df & Mean Square & $\mathrm{F}$ & Sig. \\
\hline \multirow[t]{3}{*}{1} & Regression & 642.025 & 3 & 214.008 & 979.977 & $.000 \mathrm{~b}$ \\
\hline & Residual & 20.965 & 96 & .218 & & \\
\hline & Total & 662.990 & 99 & & & \\
\hline
\end{tabular}

a. Dependent Variable: Keutusan Pembelian

b. Predictors: (Constant), Kualitas Produk, Potongan Harga, Iklan

\section{Pengujian Hipotesis Pertama (Uji F)}

Berdasarkan tabel tersebut, pengujian menggunakan Uji $\mathrm{F}$ hasil perhitungan sebesar 979.977 dengan nilai signifikan sebesar 0,000 . Karena nilai $F_{\text {hitung }}$ lebih besar daripada $\mathrm{F}_{\text {tabel }}(979.977 \geq 2,70)$ dan taraf lebih kecil dari 0,05 maka keputusan H0 ditolak pada taraf $\mathrm{a}=0,05$ sehinga dapat disimpulkan bahwa terdapat pengaruh simultan dari variabel potongan harga, iklan dan kualitas produk terhadap variabel keputusan pembelian.

\section{Pengujian Hipotesis Kedua (Uji t)}

Dari hasil perhitungan pada tabel 5 didapatkan nilai $t_{\text {hitung }}$ untuk variabel Potongan Harga sebesar 8.736 dengan tingkat signifikasi yang dihasilkan sebesar 0,000. Oleh karena nilai $\mathrm{t}_{\text {hitung }}(8.736)>\mathrm{t}_{\text {tabel }}(1,66088)$ dan nilai signifikasi yang dihasilkan sebesar 0.000. lebih kecil dari 0,05 maka H0 ditola $\mathrm{k}$ dan H1 diterima artinya bahwa variabel bebas Potongan Harga secara parsial berpengar uh signifikan terhadap variabel terikat Keputusan Pembelian. 
Dari hasil perhitungan didapatkan nilai thitung untuk iklan sebesar -2.742 dengan tingkat signifikan 0,007 . Oleh karena nilai $t_{\text {hitung }}(-2.742)>t_{\text {tabel }}(1,66088)$ dan nilai signifikasi yang dihasilkan sebesar 0,007 lebih kecil dari 0,05 maka $\mathrm{H} 0$ ditolak dan H1 diterima artinya bahwa variabel bebas Iklan secara parsial berpengaruh signifikan terhadap variabel terikat Keputusan Pembelian.

Dari hasil perhitungan didapatkan nilai thitung untuk Kualitas Produk sebesar 10.202 dengan tingkat signifikan 0,000. Oleh karena nilai $t_{\text {hitung }} \quad(10.202)>t_{\text {tabel }}$ $(1,66088)$ dan nilai signifikasi yang dihasilkan sebesar 0,000 lebih kec il dari 0,05 maka H0 ditolak dan H1 diterima artinya bahwa variabel bebas Kualitas Produk secara parsial berpengaruh signifikan terhadap variabel terikat Keputusan Pembelian.

\section{Pengujian Hipotesis Ketiga (Variabel Yang Dominan)}

Dari tiga variabel bebas yang terdiri dari Potongan Harga (X1), Iklan (X2), Kualitas Produk (X3), dapat diketahui bahwa variabel Kualitas Produk mempunyai nilai koefisien $\beta$ (beta) terbesar yaitu 0,785 yang merupakan nilai terbesar diantara variabel-variabel bebas yang lain. Sehingga dapat disimpulkan bahwa variabel bebas yang berpengaruh dominan terhadap variabel terikat Keputusan Pembelian adalah variabel Kualitas Produk.

\section{Tabel 5}

\section{Hasil Pengujian Parsial (Uji t)} Coefficients

\begin{tabular}{llll}
\hline Model & & T & Sig. \\
\hline 1 & (Constant) & 2.875 & .005 \\
& Potongan & 8.736 & .000 \\
& Harga Iklan & -2.742 & .007 \\
& Kualitas Produk & 10.202 & .000 \\
\hline
\end{tabular}

a. Dependent Variable: Keputusan Pembelian

Sumber: Peneliti (2021)

Tabel 6

Tabel Nilai Korelasi Parsial Coefficients $^{\mathrm{a}}$

\begin{tabular}{llc}
\hline Model & Standardized Coefficients \\
& & Beta \\
\hline 1 & (Constant) & .379 \\
& Potongan Harga & -.168 \\
& Iklan & .785 \\
\hline
\end{tabular}

a. Dependent Variable: Keputusan Pembelian

Sumber: Peneliti (2021) 
Pengaruh Parsial Potongan Harga (X1), Iklan (X2), dan Kualitas Produk (X3) terhadap Keputusan Pembelian (Y)

Pengaruh Secara Parsial Potongan Harga Terhadap Keputusan Pembelian

Dalam penelitian ini, pengujian secara parsial dengan uji t untuk mengetahui pengaruh variabel Potongan Harga terhadap Keputusan Pembelian diperoleh nilai thitung untuk variabel Potongan Harga sebesar 8,736 dengan tingkat signifikasi yang dihasilkan sebesar 0,000 . Oleh karena nilai thitung $(8,736)>$ tabel $(1,66140)$ dan nilai signifikasi yang dihasilkan sebesar 0,000 lebih kecil dari 0,05 maka H0 dito lak dan H1 diterima artinya bahwa variabel bebas Potongan Harga secara parsial berpengaruh signifikan terhadap variabel terikat Keputusan Pembelian.

Indikator yang mempunyai skor tertinggi pada variabel Potongan Harga adalah indikator potongan harga tunai, pada pernyataan "Potongan harga pada display produk membuat pengguna shopee di Universitas Bhayangkara Surabaya terdorong untuk melakukan pembelian di shopee" dengan nilai mean 4,40. Sedangkan indikator yang mempunyai mean terendah adalah potongan (Allowance), pada pernyataan "Shopee memberikan potongan yang cukup besar" dengan nilai mean 4,15.

Kesimpulan dari pernyataan diatas adalah ketika konsumen akan tertarik melakukan keputusan pembelian jika penjual memberikan banyak potongan harga di momen-momen tertentu.

Saran dari pernyataan diatas adalah sebaiknya penjual memberikan potongan harga yang sesuai atau pada momen tertentu memberikan potongan harga yang cukup besar agar konsumen lebih tertarik untuk membeli suatu produk.

\section{Pengaruh Secara Parsial Iklan terhadap Keputusan Pembelian}

Dalam penelitian ini, pengujian secara parsial dengan uji $t$ untuk mengetahui pengaruh variabel Iklan terhadap Keputusan Pembelian diperoleh nilai thitung untuk Iklan sebesar -2,742 dengan tingkat signifikan 0,001. Oleh karena nilai $t_{\text {hitung }}(-2,742)>t_{\text {tabel }}$ $(1,66140)$ dan nilai signifikasi yang dihasilkan sebesar 0,001 lebih kecil dari 0,05 maka H0 ditolak dan H1 diterima artinya bahwa variabel bebas Iklan secara parsial berpengaruh signifikan terhadap variabel terikat Keputusa n Pembelian.

Indikator yang mempunyai skor tertinggi pada variabel Iklan adalah indikator warna dan music, pada pernyataan "Iklan shopee memiliki music/lagu yang mudah diingat" dengan nilai mean 4,40. Sedangkan indikator yang mempunyai mean terendah adalah naskah, pada pernyataan "Naskah pada iklan shopee dapat di mengerti dan kreatif' dengan nilai mean 4,14.

Kesimpulan dari pernyataan di atas adalah bahwa suatu konsumen akan melakukan keputusan pembelian apabila media promosi atau iklan yang digunakan penjual dalam memberikan informasi tentang shopee kepada konsumen dengan sangat baik dan konsumen mendapatkan informasi yang baik dan kepuasan apabila membeli suatu produk dari shopee.

Saran dari pernyataan di atas adalah bahwa shopee harus selalu memberikan iklan yang kreatif melalui media agar konsumen yang akan membeli produk mereka bisa mengetahui informasi dan menciptakan keputusan pembelian. 
Pengaruh Secara Parsial Kualitas Produk terhadap Keputusan Pembelian

Dalam penelitian ini, pengujian secara parsi al dengan uji t untuk mengetahui pengaruh variabel Kualitas Produk terhadap Keputusan Pembelian diperoleh nilai thitung untuk Kualitas Produk sebesar 10,202 dengan tingkat signifikan 0,001. Oleh karena nilai thitung $(10,202)>$ ttabel $(1,66140)$ dan nilai signifikasi yang dihasilkan sebesar 0,001 lebih kecil dari 0,05 maka $\mathrm{H} 0$ ditolak dan $\mathrm{H} 1$ diterima artinya bahwa variabel bebas Kualitas Produk secara parsial berpengaruh signifikan terhadap variabel terikat Keputusan Pembelian.

Indikator yang mempunyai skor tertinggi pada variabel Kualitas Produk adalah indikator keistimewaan, pada pernyataan "Shopee memiliki keunggul an daripada e-commerce lainnya" dengan nilai mean 4,39. Sedangkan indikator yang mempunyai mean terendah adalah daya tahan, pada pernyataan "Shopee memiliki daya tahan yang kuat di pasaran" dengan nilai mean 4,14.

Kesimpulan dari pernyataan di atas adalah bahwa suatu konsumen akan merasakan kepuasan apabila penjual memberikan kemudahan informasi produk pada konsumen.

Saran dari pernyataan di atas adalah bahwa suatu perusahaan harus selalu memberikan informasi yang cukup untuk setiap konsumen yang akan membel i produk mereka agar mampu menciptakan keputusan pembelian.

Variabel Bebas yang Berpengaruh Dominan terhadap Keputusan Pembelian Pada ketiga hipotesis menyatakan bahwa Kualitas Produk berpengar uh dominan terhadap Keputusan Pembelian di Shopee studi kasus pengguna shopee di Universitas Bhayangkara Surabaya. Dari tiga variabel bebas yang terdiri dari Potongan Harga, Iklan, dan Kualitas Produk dapat diketahui bahwa variabel Kualitas Produk mempunyai koefesien $\beta$ (beta) terbesar yaitu 0,785 yang merupakan nilai terbesar diantara variabel -variabel bebas yang lain. Sehingga dapat disimpulkan bahwa H0 ditolak H1 diterima yang berarti bahwa variabel Kualita s Produk berpengaruh dominan terhadap Keputusan Pembelian konsumen di shopee studi kasus pengguna shopee di Universitas Bhayangkara Surabaya.

\section{SIMPULAN DAN SARAN}

Berdasarkan hasil yang sudah dilakukan mengenai variabel Potongan Harga, Iklan, dan Kualitas Produk terhadap Keputusan Pembelian di Shopee, maka dapat diambil kesimpulan, Berdasarkan pengujian menggunakan Uji $\mathrm{F}$ hasil perhitungan sebesar 979.977 dengan nilai signifikan sebesar 0,000. Karena nilai Fhitung lebih besar daripada Ftabel (979.977 $\geq 2,70)$ dan taraf lebih kecil dari 0,05 maka keputusan H0 ditolak pada taraf $a=0,05$ sehinga dapat disimpulkan bahwa variabel Potongan Harga (X1) Iklan (X2) dan Kualitas Produk (X3) secara simultan berpengaruh signifikan terhadap keputusan pembelian (Y) di Shopee Studi Kasus Pengguna Shopee di Universitas Bhayangkara Surabaya. Sehingga hipotesis penulis yang menyatakan "Bahwa variabel potongan harga, iklan, dan kualitas produk secara simultan berpengaruh signifikan terhadap keputusan pembelian" dapat diterima. Berdasarkan perhitungan secara Parsial (Uji t) maka dapat disimpulkan sebagai berikut, berdasarkan uji parsial untuk variabel bebas berupa Potongan Harga (X1) diperoleh nilai thitung untuk variabel Potongan Harga sebesar 8,736 dengan tingkat signifikasi yang dihasilkan sebesar 0,000. Oleh karena nilai 
thitung $(8,736)>$ ttabel $(1,66140)$ dan nilai signifikasi yang dihasilkan sebesar 0,000 lebih kecil dari 0,05 maka $\mathrm{H} 0$ ditolak dan $\mathrm{H} 1$ diterima artinya bahwa variabel bebas Potongan Harga secara parsial berpengaruh signifikan terhadap variabel terikat Keputusan Pembelian. Berdasarkan uji parsial untuk variabel bebas berupa Iklan ( X2) diperoleh nilai thitung untuk Iklan sebesar -2,742 dengan tingkat signifikan 0,001. Oleh karena nilai thitung $(-2,742)>$ ttabel $(1,66140)$ dan nilai signifikasi yang dihasilkan sebesar 0,001 lebih kecil dari 0,05 maka H0 ditolak dan H1 diterima artinya bahwa variabel bebas Iklan secara parsial berpengaruh signifikan terhadap variabel terikat Keputusan Pembelian. Berdasarkan uji parsial untuk variabel bebas berupa Kualitas Produk (X3) diperoleh nilai thitung untuk Kualitas Produk sebesar 10,202 dengan tingkat signifikan 0,001 . Oleh karena nilai thitung $(10,202)>$ ttabel $(1,66140)$ dan nilai signifikasi yang dihasilkan sebesar 0,001 lebih kecil dari 0,05 maka H0 ditolak dan H1 diterima artinya bahwa variabel bebas Kualitas Produk secara parsial berpengaruh signifikan terhadap variabel terikat Keputusan Pembelian. Diantara ketiga variabel yaitu Potongan Harga, Iklan, dan Kuali tas Produk variabel yang paling dominan yaitu variabel Kualitas Produk dengan nilai koefisien $\beta$ (beta) sebesar 0,785 terhadap keputusan pembelian dapat disimpulkan bahwa H0 ditolak H1 diterima. Sehingga hipotesis penulis yang menyatakan "bahwa variabel Kualitas Produk berpengaruh dominan terhadap Keputusan Pembelian konsumen di shopee studi kasus pengguna shopee di Universitas Bhayangkara Surabaya" dapat diterima. Berdasarkan hasil penelitian yang telah dilakukan maka diajukan saran-saran bagi Shopee. Perusahaan hendaknya memahami keinginan konsumen agar Shopee dapat terus bertahan dalam persaingan yang semakin kompetitif. Yang bisa dilakukan adalah pihak Shopee tetap mempertahankan program potongan harga yang diadakan sehingga konsumen akan tetap setia belanja di Shopee, selain itu juga tampilan ulasan produk di Shopee harus lebih kreatif dan pihak Shopee harus lebih giat mensosialisasikan fitur ulasan produk kepada pengguna Shopee agar pengguna Shopee mengetahui adanya fitur ulasan produk dan dapat menggunakan fitur ulasan produk semaksimal mungki n, dan dikarenakan hasil penelitian yang menyatakan variabel iklan mempunyai pengaruh terendah terhadap keputusan pembelian artinya promosi produk melalui iklan perlu ditingkatkan dengan mengusung iklan yang unik, inovatif dan mudah diingat oleh konsumen maka hal ini akan meningkatkan penjualan di Shopee.

\section{DAFTAR PUSTAKA}

Wahyuni, Sri., Jonianto Pardamean. 2016. Pengaruh Iklan, Harga Dan Kualitas Layanan Terhadap Keputusan Pembelian Kartu Simpati Di Institute Perbanas Jakarta. Jurnal. Jakarta: Institute Perbanas.

Prabarini, Anggun., Budi Heryanto., dan Astuti. 2018. Pengaruh Promosi Penjualan Dan Potongan Harga Terhadap Keputusan Pembelian Konsumen Produk Kecantikan Wardah Di Toserba Borobudur Kediri . Jurnal. Kediri: UNIK. 
https://apjii.or.id/. 2017.

https://databooks.katadata.co.id/. 2018.

https://id.wikipedia.org/wiki/Shopee. 2018.

https://industri.kontan.co.id/news/per-16-desember-2018-belanja-iklan- perusahaanmarketplace-capai-rp-497-triliun. 2018.https://shopee.co.id/. 2018.

https:/_www.indotelko.com/read/1543462517/pertumbuhan-pengguna- shopee.2018.

Hasibuan, P.S., Malayu.2016. Manajemen Sumber Daya Manusia. Jakarta: PT. Bumi Aksara.

Dewantoro, Shandy. 2020. Pengaruh Kualitas Produk, Kualitas Layanan Dan Harga Terhadap Keputusan Pembelian Di E-Commerce Tokopedia.com. Jurnal. Surakarta: Universitas Muhammadi yah Surakarta.

Sugiyono, 2015, Metode Penelitian Kuantitatif, Kualitatif, dan R\&D, Alfabeta, Bandung.

Sugiyono, 2016, Metode Penelitian Pendidikan Pendekatan Kuantitatif, Kualitatif, dan R\&D. Bandung: Alfabeta.

Sudaryono. 2016. Manajemen Pemasaran Teori Dan Implementsi. Yogyakarta: ANDI

Sugiyono, 2017, Metode Penelitian Kuantitatif, Kualitatif, dan R\&D, Alfabeta, Bandung.

Suparyanto dan Rosad. 2015. Manajemen Pemasaran. IN MEDIA: Bogor.

Priansa, Donni Juni. 2017. Perilaku Konsumen dalam Persaingan Bisnis Kontemporer. Bandung: Alfabeta.

Isti'adah, Diah Ayu. 2016. Pengaruh Diskon Harga, Varian Produk dan Citra Toko Terhadap Minat Beli Konsumen di Toserba Berkah Bangsri Jepara. Jurnal. Kudus: STAIN Kudus.

Tjiptono, Fandy. 2014. Pemasaran Jasa: Prinsip, Penerapan dan Penelitian. Yogyakarta: Penerbit Andi.

Tjiptono, Fandy. 2015. Strategi Pemasaran. Edisi 4. Yogyakarta: Penerbit Andi. Kotler, Philip,. \& Keller, Kevin. 2016. Marketing Management. Edisi ke 15. Penerbit Pearson Education Limited 2016.

Kotler, Armstrong 2015. Marketing an Introducing Prentice Hall twlfth edition. England: Pearson Education, Inc 
Kotler, Philip dan Gary Amstrong. 2016. Principles Of Marketing, Globa Edition, 17 Edition, Pearson Education.

Kotler, Keller. (2016). Manajemen Pemasaran. Edisi 13 Jilid 1.Jakarta : Erlangga

Pratama, Eka. 2015. E-Commerce, E-Business dan Mobile Commerce. Bandung: Informatika Bandung.

Rachman, Mochammad Munir. 2017. Metedologi Penelitian. Surabaya: UNIPRESS Universitas PGRI Adi Buana.

Sudaryono. 2017. Pengantar Manajemen: Teori dan Kasus. Yogyakarta: CAPS.

Ghozali, Imam. 2018, “Aplikasi Analisis Multivariate Dengan Program IBM SPSS 25”. Semarang: Universitas Diponegoro 